\title{
国立大学におけるキャンパス計画ならびに施設・環境に関する 問題の構造化

\author{
STRUCTURAL MODELING OF PROBLEMS CONCERNING PLANNING AND \\ BUILT ENVIRONMENT ON NATIONAL UNIVERSITY CAMPUSES
}

\author{
山口勝 已*, 谷口汎邦**, 高野文雄*** \\ Katsumi YAMAGUCHI, Hirokuni TANIGUCHI and Fumio TAKANO
}

\begin{abstract}
This paper aims to clarify the structure of problems concerning planning and built environment on national university campuses by using DEMATEL method. At first, 38 problems are selected and interrelations of these problems are investigated. Secondly, the structural model of these problems is constructed in the form of a multilevel digraph. Finally, main routes of influences are extracted through an inspection of this structural model.
\end{abstract}

Keywords : campus planning, DEMATEL method, structural model, questionnaire キャンパス計画, DEMATEL 法, 構造モデル, アンケート調査

1.はじめに

現在の国立大学キャンパス ${ }^{\natural 1}$ では，理工系を中心と する学部・学科・講座增による施設の増加や建築密度の 上昇；建物の老朽化，計画性の低い施設の新増築，など により教育・研究環境の悪化が問題となっている。その 対策として再開発なざが検討されているところが多く, 将来にわたって良好な環境を保つために有効な施設将来 計画の策定が求められている。しかし, 大学院・学部・ 学科なざの教育研究計画や,これにともなう組織の将来 計画が確定されないままに，その時点のニーズに対応し て施設整備を迫られることも少なくないため，一貫した 計画でキャンパスを整備することは困難であり，いかに して不確定な変化に対応できる計画とするかが大きな課 題となっている。また, 大学施設には研究室, 講義室, 実験室, 図書館, 体育館, 福利厚生施設なE゙, 教育・研 究と生活に関わる機能は多様であり, 利用者も学生・教 官・職員などと幅広いため, 大学キャンパスの施設・環 境に関して発生する問題も多岐にわたっている。最近で は, キャンパス周辺地域との間で発生する問題も多い。 計画策定面でも，施設面積や予算の制約，組織間の調整 の難しさなど様々な問題をかかえている。
このような状沉では，これらの多種，多様な問題の解 決策を含んだ効果的な施設将来計画を策定することは非 常に難しいことである。樣々な問題が複雑に絡み合って いる場合，個々の問題ごとに対策を考えていたのでは有 効な解決策は得られない。まずキャンパス計画や施設・ 環境に関係する問題をすべて抽出し，問題相互の影響関 係をもとに問題の全体像を明らかにすることが必要であ ると思われる。

本研究では, 国立大学のキャンパス計画と施設・環境 に関する問題について, システムズアナリシスで用いら れる構造モデル法を適用し，問題相互の影響関係を施設 担当者の認識を通して把握することにより，問題全体の 構造と問題の波及過程を明らかにすることを目的として いる。これにより総合的視野で大学キャンパス計画を考 えることが可能になり，施設将来計画の策定に関して有 効な知見が得られると思われる。

大学施設に関する既往研究としては, 丸茂齐が大学 キャンパスの建て詰まりを取り上げており，大学キャン パスにおける土地利用が高度化されない要因として, 低 層指向施設の存在, 施設整備単位の小規模性, 組織の独 立指向性による施設・敷地の細分化を指摘している。本

* 東京工業大学文教施設総合研究センター 助手・ Research Assoc., Research Center for Educational Facilities, Tokyo 修士 (工学)

** 武蔵工業大学工学部建築学科 教授・博士 (工学) Institute of Technology, M. Eng.

Prof., Dept. of Architecture and Building Engineering, Faculty of Engineering, Musashi Institute of Technology, Dr. Eng. **** 東京工業大学文教施設総合研究センター 客員教 $\begin{aligned} & \text { Visiting Prof., Research Center for Educational Facilities, Tokyo In- } \\ & \text { stitute of Technology }\end{aligned}$
授 
研究においても，これらはキャンパス計画策定上重要な 問題であると考え, 分析の対象となる問題項目として採 用し，施設担当者の認識を通して問題の存在を確認する とともに，他の問題項目との影響関係を把握することに より問題構造全体の中に位置つけることを試みている。 他には，外部空間に関する研究济21，施設配置に関する 研究注3), 施設規模に関する研究涪4), キャンパス内交通 に関する研究注5), 学生行動に関する研究㐬 61 , キャンパ 又計画に関する研究注7なよ゙があるが，これらはいずれ も大学施設の特定の面だけを取り上げており，大学キャ ンパスの施設・環境全般に関する問題構造を明らかにす ることは，個々の既往研究の位置づけを明確にするうえ でも意義あるものと考えられる。

\section{2. 研究の方法}

大学施設に関する問題のように複雑に絡み合う問題群 を問題複合体というが，この問題複合体の全体像を明確 化するためには構造モデル法を用いることが有効であ る。構造モデル法とは, 問題複合体を個々の問題を要素 とした一つのシステムとしてとらえ, 要素間の関係より システム全体の構造をモデル化し視覚的に表見すること によって, 複雑なシステムの分析を容易にしようとする ものである。代表的な構造モデル法として, 要素間の関 係づけに一対比較法を用いる ISM 法注8), DEMATEL 法注9)開発されている。一対比較法とは，2つの要素だ けを取りだしその関係の程度などを比較する方法であ り，システム全体を見渡しながら要素間の位置づけを行

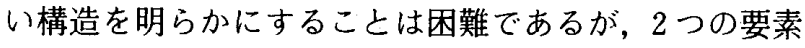
だけを取り出して比較することは容易であり精度ある判
断を行うことができるという考えに基づいている。 ISM 法は回答者を一同に集めて行うため，そのグルー プ内における問題複合体に対する共通認識を深めたりグ ループの合意形成プロセスの一部として有効とされてい る。DEMȦTEL 法は, その問題複合体に関して專門的 立場にいる人からアンケート調查により回答を集め，問 題構造を明らかにしようとするものである。本研究では, 各大学の施設担当者がもっている意見を集約することに より，大学施設に関する問題複合体の構造を解明するこ とを目的としているため，DEMATEL 法を採用した。 ただし，分析の中ではISM 法で用いられている多階層 有向グラフによる構造モデルの作成方法も使用してい る。

\subsection{DEMATEL 法の概要}

DEMATEL 法は，複雑な問題複合体の構造を把握す ることを目的に開発された手法であり，構造モデルを作 成し階層的に表現することができる。その手順は以下に 示す通りである。

（1）問題項目の収集，選定を行う。

（2）問題項目ごとにアンケートを作成する。その内容 は，以下のような質問から構成される。なお，提示され た問題項目以外に問題亡なっている項目があると考えら れる場合には，追加することが可能である。

(1) その問題項目が現実に問題となっているか否か注10)。

(2) その問題項目はどの程度重要が士11。

(3) その問題項目の解決または軽减が, 他のどの問題項 目に直接影響を及ぼすか。またその影響の程度は辛22)。

（3）得られた回答から求めた影響行列を用い, 問題項 目の影響度・関連度による分析や多階層有向グラフによ

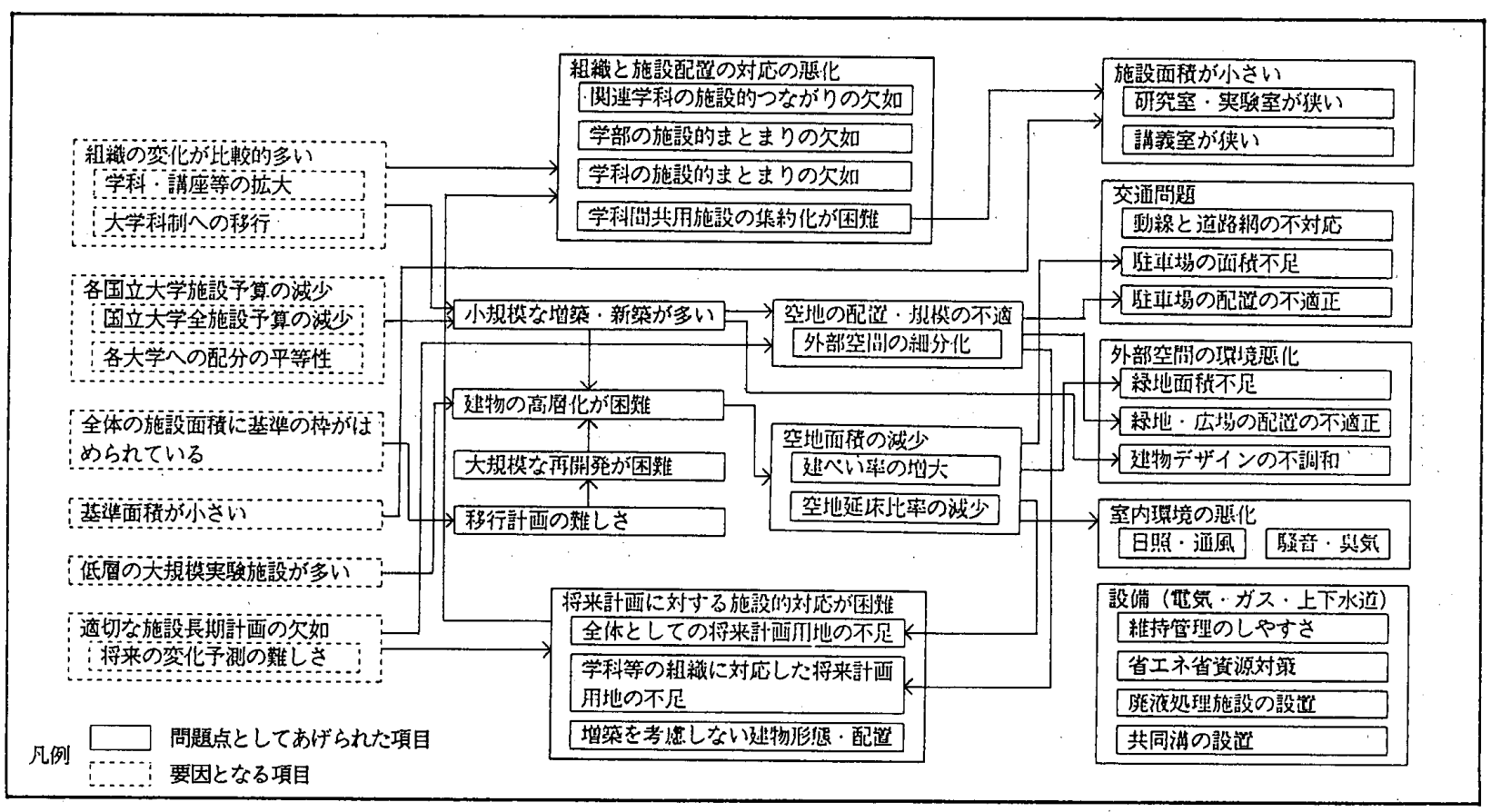

図一1 工科系学部における問題構造 
る表示を行い，構造モデルを作成する。

（4）得られた構造モデルより，全体の中での各問題項

目の位置づけ, 問題項目間の因果関係などについて解釈 を行う。

\section{2 工科系学部における予備調查}

問題複合体を構造化するためには，まず現実によ゙のよ うな問題が存在しているか明らかにしなければならな い。そのために，施設の規模・増加量の大きさなどから， 国立大学施設の中で施設・環境の問題が最も多く発生し ていると思われる工科系学部を取り上げ，工科系学部の 施設整備を行ううえで現在問題となっている項目の抽出 とそれらの問題項目間の関係について予備的に調查・分 析を行った。

大学施設に関する既往研究や各国立大学施設部課に対

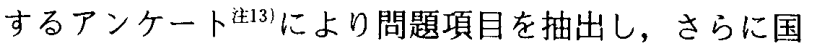
立大学施設の関係者へのヒヤリングなどによって得られ た問題発生の要因を加え, KJ 法を用いてこれら問題項 目の検討・整理と因果関係の考察を行った。その結果を 図一1に示す。

交通問題, 外部空間の環境悪化, 室内環境などの施設 環境に関する問題が発生する直接的な要因としては，空 地面積が小さいこと，空地の配置が適切でないことがあ げられるが，これを解決するために必要な建物の高層化 がかなり困難な状況である。その理由としては，施設予 算の制約で小規模の増築・新築が多いこと，低層の実験 棟が多いこと，移行計画をたてるための床面積に余裕が ないことなどがあげられている。他には，組織と施設配 置の対応が悪化していること，将来計画に対する施設的 対応が困難であることなよ゙が問題とされている。

\section{3 問題項目の設定}

工科系学部施設の分析で得られた問題項目をもとに, さらに大学施設関連の既往研究・文献の調査や大学施設 関係者に対するヒヤリングにより大学施設に関する問題 項目を収集した注14)。これらの問題項目について，内容 の類似した項目の集約や重要性などを考慮した取捨選択 を行い，表一 1 に示す 38 項目を選定した。これらは大 きく分けると計画策定に関する問題項目之実際の施設 · 環境に関する問題項目から構成されている。なお本研究 では, 再開発計画, 施設長期計画に関する知見を得るこ とを念頭においているため, 主に土地利用・施設配置・ 空間構成についての問題を中心とし，実験室・研究室の 面積や室構成など建物内の問題については扱わないこと とした。

\section{4 調查の方法}

DEMATEL 法における回答者は，その問題に精通し ている人が望ましいとされている。そこで，国立大学施 設の計画・維持管理を行い，問題の全体像を把握してい ると思われる各大学の施設部課を対象とした。調査は,
表一1 キャンパス計画と施設・環境に関する問題項目

《計画面〉

1. 国立大学における施設予算の少なさ

2. 将来の変化予測の難しさ

3. 教育・研究組織や教育システムの将来計画の欠如

4. 施設将来計画の内容の不備および有効な計画手法の欠如

5. 施設影画策定における利用者の意向反映の不足および利用者 の計画内容の理解の不足

6. 再開発計画における建設プロセス決定の難しさ

7. 大学キャンパス全体の土地面積の不足

8. 立地条件による建物形態（高さなぞ）・面積・建設位置・施 設内容の制限

9. 教地条件による制限

10. ゾーン計画の不適正

11. 組織の教地・建物における独立性への指向となわばり意識

12. 建物の取り罣しの制限

13. 建物面積基準による面積拡大要求への制限

14. 建物の小規模化 $\cdot$ 細分化

15. 建物の高層化の難しさ

16. 土地の立体的利用の欠如

17. 学部・研究所ゾーン間における建物密度のかたより

18. 増策や近接した新筑に対応しにくい建物群の形態

19. 将来計画用地面積の不足

20. 将来計画用地の配置の不適正

21. 建べい率の增大

22. 容積率の增大

\section{〈施設・環境面》}

23. 室内環境（日照・採光・通風など）の悪化

24. 学部・学科・研究所などの施設面積の不足

25. 学部・学科施設のまとまりの欠如

26. 関連した学部・学科の施設面でのつながりの欠如

27. 共同利用施設面積の不足

28. 共同利用施設の配置の不適正

29. 外部空間における施設・環境デザインの欠如

30. 交流の場・休息の場の不足

31. 屋外運動場面積の不足

32. 緑地・庄場面積の不足

33. 緑地・広場の配置の不適正

34. 駐車・駐輪スペースの不足

35. 駐車・駐輪スペースの配置の不適正

36. 歩行者・自動車の動線や設備の配線・配管之道路網の不対応 37. 歩行者・自転車の安全性への未対策

38. 設備関係の施設の未整備

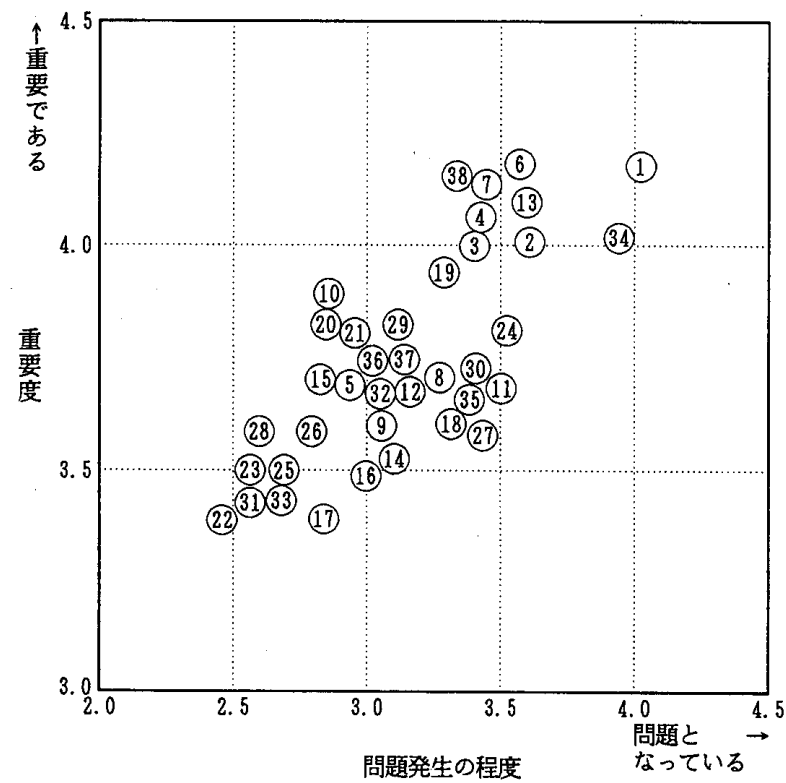

図一2 問題発生の程度と重要度 
1989 年 12 月に全国立大学 95 大学に対し郵送で行い, 87 大学（回収率 $91.6 \%$ ）加回答を得た。

\section{3. 問題発生の程度と問題の重要度}

まず，38 項目の問題を選定した妥当性を確認するた めに，追加された問題項目の内容と現在どのくらい問題 になっているかという問題発生の程度について検討し た。問題発生の程度で [問題となっていない]，[あまり 問題となっていない] と回答した大学は最も多い項目で 49 校 $(56.3 \%)$ であり，38 項目すべてが多くの大学で 問題と認識されていることがわかる。また，追加された 問題項目は 59 項目あるが，ほとんどが内容的に 38 項目 と重複しているものであった。これより，選定した 38 項目は施設担当者が認識している問題の全体をほぼ網羅 していると思われる。

次に, 各問題項目の問題発生の程度と問題の重要度に ついて，それぞれ 5 段階尺度上の回答を 1 ～5 に点数化 し, 平均值を求めた (図一 2$)$ 。問題発生の程度, 重要度 とも高いのは， [1．施設予算の少なさ]， [13．建物面積 基準による面積拡大要求への制限 $]$ の施設行政問題, [2. 将来の変化予測の難しさ $],[3$. 組織や教育システムの 将来計画の欠如] の将来予測の問題, [4. 計画内容の不 備・有効な計画手法の欠如 $],$ [6. 建設プロセス決定の 難しさ] の計画手法の問題, なよ゙計画面の問題であるが, 施設・環境面でも [34. 駐車スペースの不足]，[38．設 備関係の施設の未整備] があげられており，これらは施 設担当者にとって差し迫った問題であると思われる。
問題発生の程度, 重要度とも低いのは [22. 容積率の 増大], [31. 屋外運動場面積の不足 ], [33. 緑地 - 広場 の配置の不適正], [23. 室内環境の悪化], [25. 学部 学科施設のまとまりの欠如 $],[28$. 共同利用施設の配置 の不適正）などである。施設面積の確保が施設担当者の 直接的問題のため, 配置に関する問題が低くなっている と思われる。

また，あまり重要度は高くないが，問題となっている 項目は，[11．組織の独立性への指向となわばり意識], [18. 増築などに対応しにくい建物群の形態]，[27．共 同利用施設面積の不足 $],[30$. 交流の場・休息の場の不 足] などであるが，27，30より生活スペースに対してゃ や軽視する傾向がうかがわれる。

\section{4. 問題の構造化}

問題複合体の構造を明らかにするため，まず問題の影 響度と関連度を定義し，この数値により問題相互の位置 づけを行った。さらに，多階層有向グラフによる表現を 用い，構造モデルを作成した。

\section{1、影響度と関連度による分析}

問題複合体の全体像を把握するために, 各問題項目が それぞれ他の問題項目とどのような相対関係にあるかを 示す。そのために, 各問題項目の影響度と関連度を以下 のように定義した。

まず，アンケートの回答より項目間の直接の影響を表 す直接影響行列 $X^{*}$ が得られる（影響程度の強, 中, 弱 をそれぞれ $3 ， 2 ， 1$ ，影響なしを 0 とした)。これを行

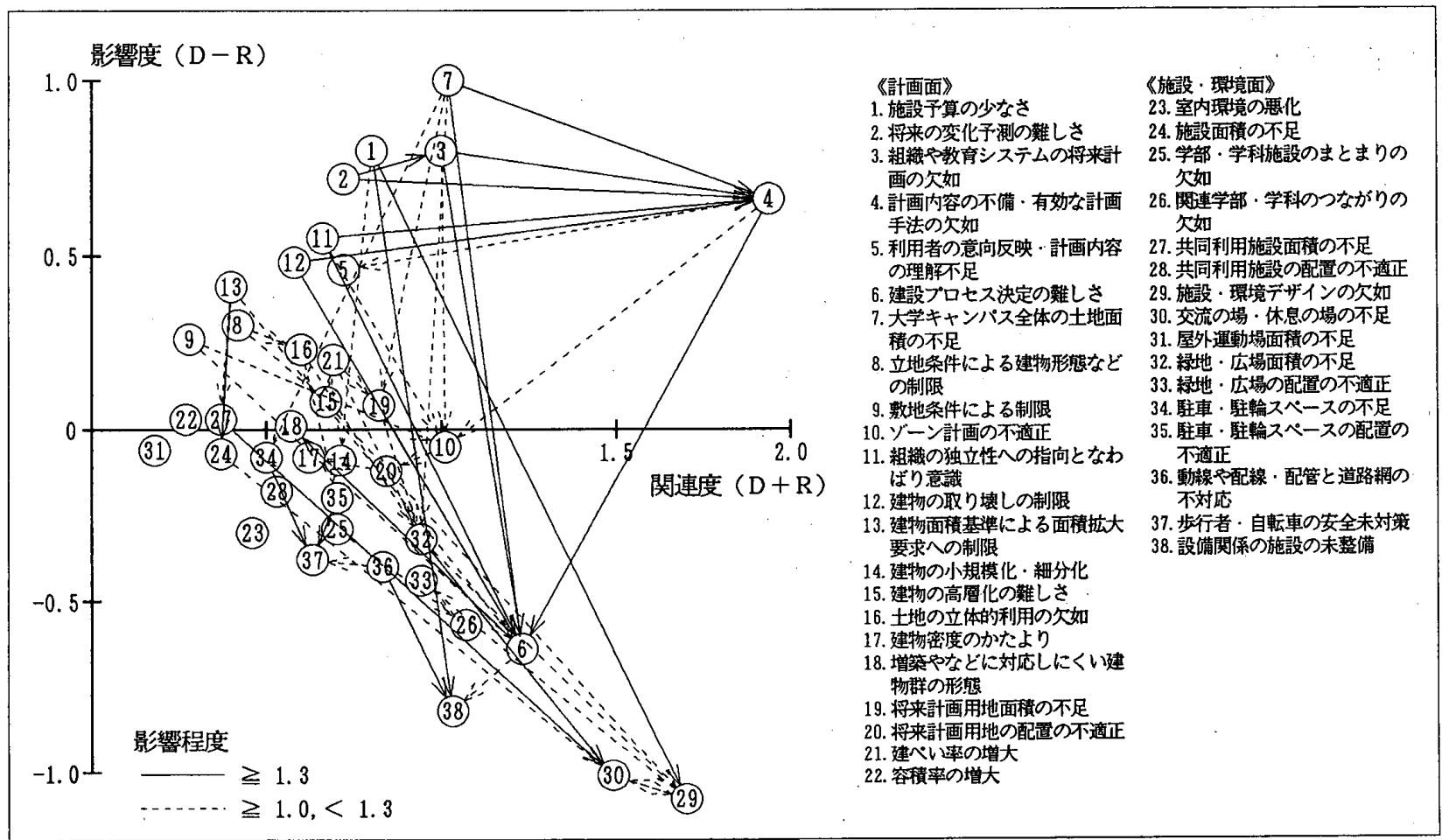

図一3 問題の関連度と重要度 
和の最大值で除した行列を正規化直接影響行列 $X$ 亡呼 ぶ。すると間接影響行列 (他の項目を介した影響を表す) は,

$$
X^{2}+X^{3}+\cdots \cdots+X^{n}=X^{2}(I-X)^{-1}
$$

で求められる。したがって, 直接影響と間接影響の合計 である総合影響行列は,

$$
X+X^{2}(I-X)^{-1}=X(I-X)^{-1}
$$

で求められる。ここで,

$$
\begin{aligned}
& D_{i}=\sum_{j} a_{i j} \\
& \left.R_{i}=\sum_{j} a_{j i} \quad \text { ( } a_{i j} \text { は総合影響行列の要素 }\right)
\end{aligned}
$$

とすると $D_{i}$ は, その項目が他の項目に与える影響の度 合いを表し，その反対に $R_{i}$ はその項目が他の項目から 受ける影響の度合いを表している。この $D_{i}, R_{i}$ を用い, 影響度を $\left(D_{i}-R_{i}\right)$ ，関連度を $\left(D_{i}+R_{i}\right)$ と定義する。

影響度亡関連度による各問題項目の平面上の布置を図 -3に示す。他の問題に大きな影響を与えているのは,

[1. 施設予算の少なさ], [2. 将来変化予測の難しさ],

[3. 組織や教育システムの将来計画の欠如], [4. 計画 内容の不備・有効な計画手法の欠如], [7. 大学キャン パス全体の土地面積の不足］など計画面の問題である。

他の問題から影響をより多く受けているのは [29. 施 設 : 環境デザインの欠如], [30. 交流の場・休息の場の 不足］の快適環境の問題や [38. 設備関係の施設の未整 備] など施設・環境面の問題が大部分であるが, 計画面 でも [6. 建設プロセス決定の難しさ] は他から受ける 影響が大きい。

また，[4. 計画内容の不備・有効な計画手法の欠如] は影響度, 関連度がともに強く, 施設担当者にとって有 効な計画手法が強く求められていることがうかがわれ る。

\section{2 多階層有向グラフによる構造モデル}

問題項目間の因果関係をより明確化させるために, ISM 法で用いられている多階層有向グラフにより図示 する方法を用いて，問題複合体の構造を階層的に表現し た。その方法を以下に示す。

あるシステムが, $n$ 個の要素 $s_{1}, s_{2}, \cdots, s_{n}$ からなる 集合 $S$ であり，この集合 $S$ 上に 2 項関係 $R$ が定義され ているとする。ここで, 要素 $s_{i}$ と $s_{j}$ が直接関係してい るとき,

$$
s_{i} R s_{j}
$$

と表す。また, 関係 $R$ は集合 $S$ の各要素を行と列にも つ 2 值行列を用いて表現することもできる。この行列 $B$ を

$$
b_{i j}= \begin{cases}1, & s_{i} R s_{j} \\ 0, & s_{i} \bar{R} s_{j}\end{cases}
$$

とおく。この行列 $B$ に単位行列 $I$ を加え, ブール代数 演算による行列の乗算を

$$
(B+I)^{\kappa+1}=(B+I)^{\kappa}=T
$$

を満たすまで行って得られた行列 $T$ を可到達行列と呼 ぶ。可到達行列 $T$ にはもとの行列 $B$ における直接的な 関係と, 関係 $R$ の推移性によって得られる間接的関係 の両方が示されている。

次に, 行列 $T$ より多階層有向グラフを得るために集 合 $S$ の各要素 $s_{i}$ に対して可到達集合 $R\left(s_{i}\right)$ および先行 集合 $A\left(s_{i}\right)$ を定義する。

$$
\begin{aligned}
& R\left(s_{i}\right)=\left\{s_{j} \in S \mid t_{i j}=1\right\} \\
& A\left(s_{i}\right)=\left\{s_{j} \in S \mid t_{j i}=1\right\}
\end{aligned}
$$

集合 $R\left(s_{i}\right)$ は要素 $s_{i}$ から到達可能なすべての要素を含 み, 集合 $A\left(s_{i}\right)$ は要素 $s_{i}$ に到達可能な要素すべてから なる。ここで，

$$
S_{1}=\left\{s_{i} \in S \mid R\left(s_{i}\right) \cap A\left(s_{i}\right)=R\left(s_{i}\right)\right\}
$$

を満足する $s_{i}$ の集合 $S_{1}$ を考える。この集合はこれに属 さない要素のどれにも到達できない要素の集合で多階層 有向グラフの最下位レベルの要素である。そしてこの要 素を行列 $T$ より除き, 再びこのプロセスを繰り返すこ とにより, 集合 $S$ はいくつかのレベルに分割され, 多 階層有向グラフが作成される。

以上の多階層有向グラフ作成のもとになる行列 $B$ を 求めるために, 回答より得られた直接影響行列の半均を 2 值行列に変換しなければならない。そこで, 境界值 $p$ を設定し $p$ 以上を $1, p$ 未満を 0 とした。 $p=0.6,0.7$ ， 0.8 の 3 種類の 2 值行列を用い多階層有向グラフを求 め, 階層の数, 問題項目間の連結を判断基準として検討 した結果, 問題複合体の構造を最も的確に表していると 思われる $p=0.7$ のグラフを構造モデルとして採用し た。そのグラフを図ー4に示す。項目間を結ぶ矢印は, 最初の平均した直接影響行列の要素間の影響関係を示 し，矢印の太さは影響の程度を示している。このグラフ は, 国立大学施設担当者のキャンパス計画と施設・環境 についての問題に対する平均的認識構造を表していると いえる。なお， [22．容積率の増大]， [23．室内環境の 悪化], [31. 屋外運動場面積の不足] の 3 つは他の問題 との関係がないため図には示されていない。

図一4の上の方の問題項目は，原因となる先行問題を 表し, 下の方の問題項目は改善目標となる問題であると いえる。先行問題は, [2. 将来変化予測の難しさ], [3. 組織や教育システムの将来計画の欠如］の将来予測の問 題や [7. 大学キャンパス全体の土地面積の不足], [9. 敷地条件による制限] の敷地問題，[1. 施設予算の少な さ], [13. 建物面積基準に上る面積拡大要求への制限], [12. 建物の取り壊しの制限] の施設行政問題, [11．組 織の独立性への指向となわばり意識]などである。また， 目標問題は，[29. 施設・環境デザインの欠如 $],[30$. 交流の場・休息の場の不足], [32. 緑地・広場面積の不 足], [33. 緑地・広場の配置の不適正] の快適環境の問 
題， [34．駐車・駐輪スペースの不足]，[35．駐車・駐 輪スペースの配置の不適正], [37. 歩行者・自転車の安 全未対策] の交通問題， [38. 設備関係の施設の未整備] などである。先行問題と目標問題をつなぐ中間問題とし て，[6．建設プロセスを決定の難しさ]，[14，建物の小 規模化・細分化]，[15．建物の高層化の難しさ]， [21. 建ぺい率の増大]，[18．増築などに対応しにくい建物群 の形態]，[19．将来計画用地面積の不足］などが位置つ けられている。

また, 図一4の多階層有向グラフより, 重要度の高い 問題項目や影響程度の強い関係，および多くの問題項目 之関係する項目に注目し，さらに問題項目の内容を考慮 しながら主要な影響ルートの抽出とその解釈を行った

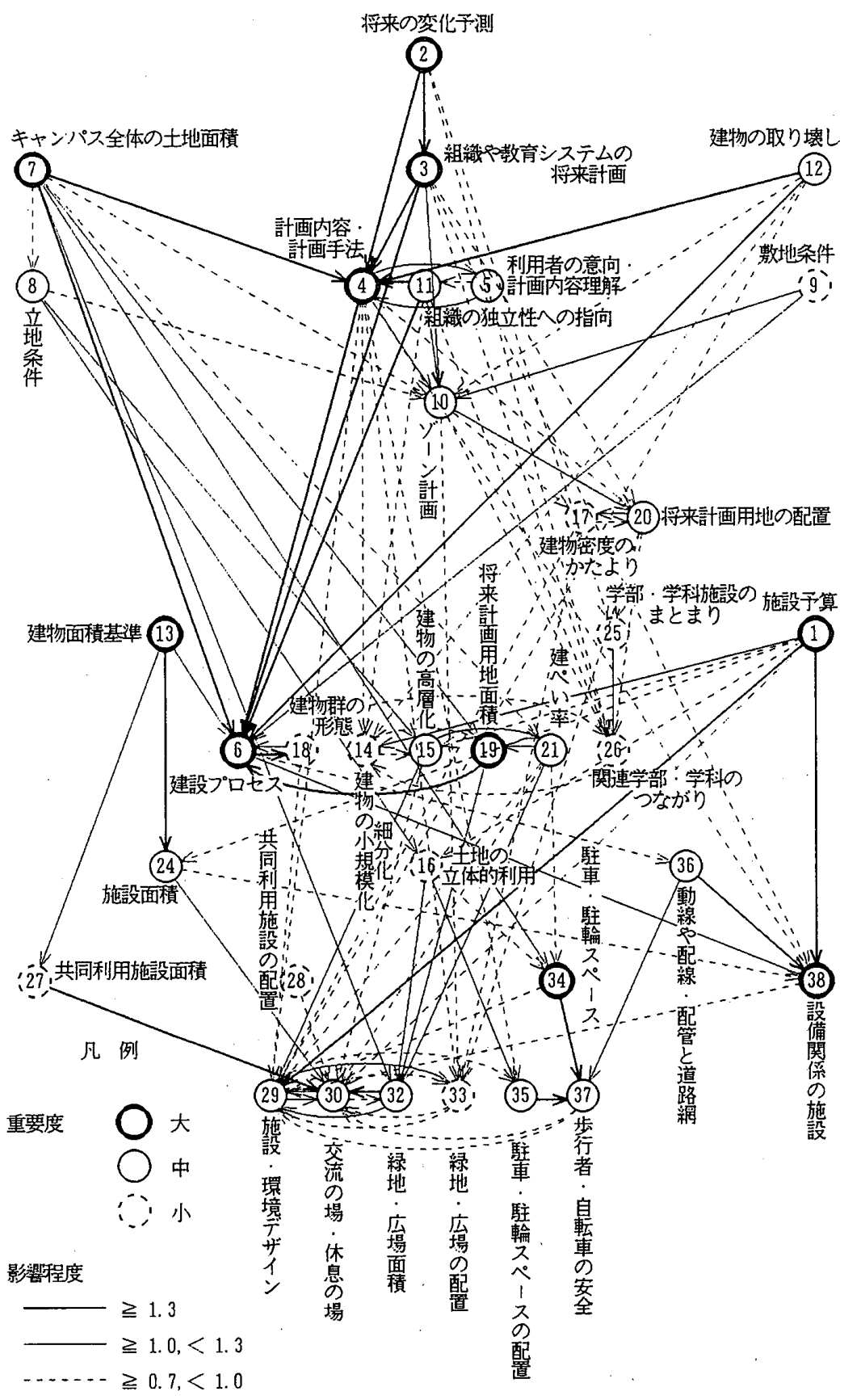

図一4 多階層有向グラフによる構造モデル
(図一5)。これより，以下のことが明らかとなった。 (1) 計画策定に関する問題は重要度が高く, 特に $[6$. 建設プロセスの決定の難しさ）が大きな問題となってい る。その原因としては, [2. 将来変化予測の難しさ ], [3.

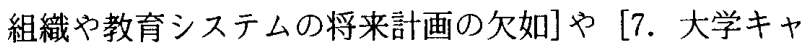
ンパス全体の土地面積の不足], [11．組織の独立性への 指向となわばり意識], [12. 建物の取り壊しの制限] に よる [4. 計画内容の不備・有効な計画手法の欠如] が あげられている。ほかに，[9.敷地条件による制限]，[13. 面積基準による面積拡大要求への制限～も原因亡なって いる。また， [4. 計画内容の不備・有効な計面手法の欠 如], [11. 組織の独立性への指向となわばり意識], [5. 利用者の意向反映・計面内容の理解不足］は，サイク ル社12) 形成しており，組織間の意見調 整の因難さおよび利用者への計画内容の 説明不足など計画策定システムに大きな 問題があることがうかがわれる。

(2) [21. 建ぺい率の増大] は空地の減 少を意味し，[29. 施設・環境デザイン の欠如 ], [30. 交流の場・休息の場の不 足], [32. 緑地・広場面積の不足], [34. 駐車・駐輪スペースの不足］などに影響 を及ぼす重要な問題である。その原因と しては，[11．組織の独立性指向やなわ ばり意識], [12. 建物の取り壊しの制限], [1. 施設予算の少なさ] が. [14. 建物の 小規模化・細分化］を引き起こし，それ が［15．建物の高層化］を妨げ [21．建 ペい率の増大]を招いていることにある。 これより，建ぺい率の増大を抑えるには， いくつかの組織を同一建物に集約化し, 高層化を図ることが重大な課題であると いえる。

(3) [6. 建設プロセスの決定の難しさ $]$ は，[18．増築などに対応しにくい建築 群の形態] と相互影響関係があり, これ が [26. 関連学部・学科のつながりの欠 如] をもたらし， [14. 建物の小規模化 · 細分化]を生み出している。さらに，(2) でも述べたように $[15$ ，建物の高層化の 難しさ], [21. 建ぺい率の増大] を通し， 結果として [19. 将来計画用地面積の不 足］に至っている。この [19. 将来計画 用地の面積不足］は初めの [6. 建設プ ロセスの決定の難しさ］を引き起こして いる一要因であり：これらの問題項目が 一つのサイクルを形成している。このサ イクルを断ち切ることは, 他の問題項目 


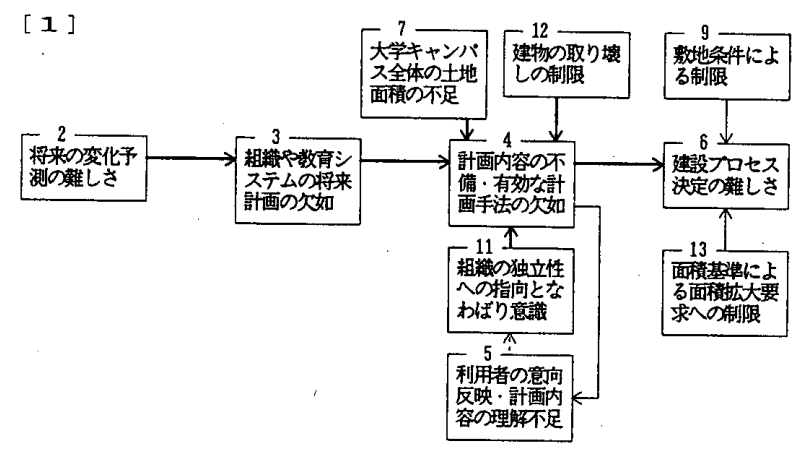

[2]

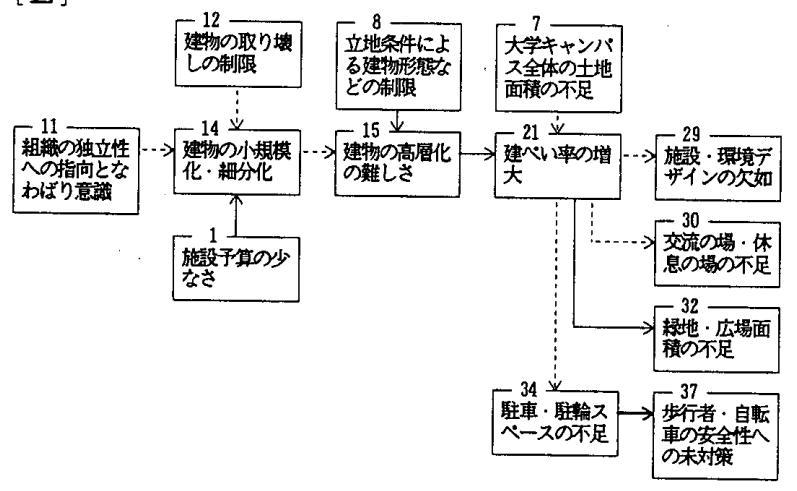

[3]

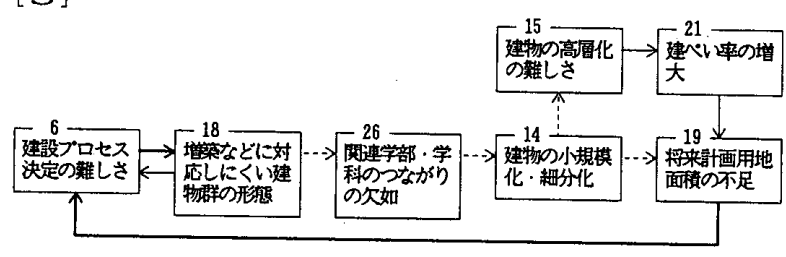

[4]

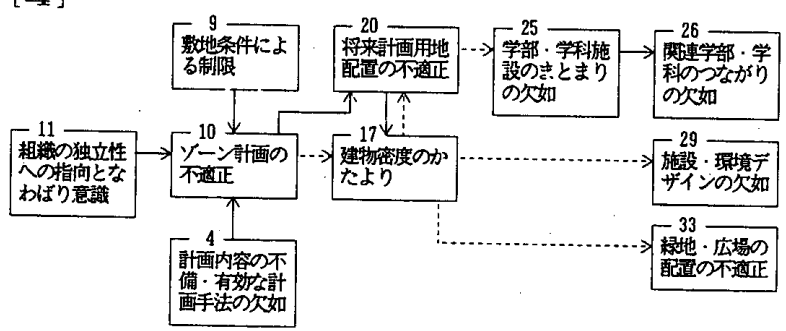

[5]

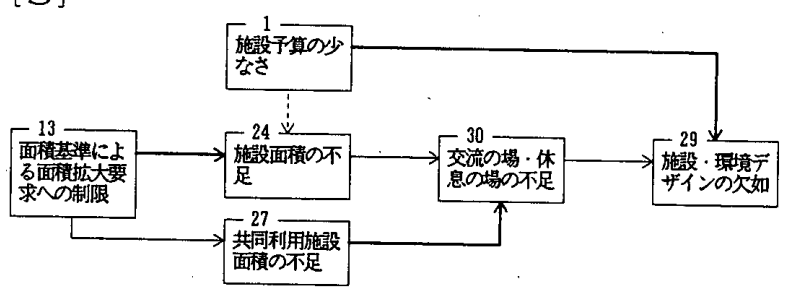

[6]

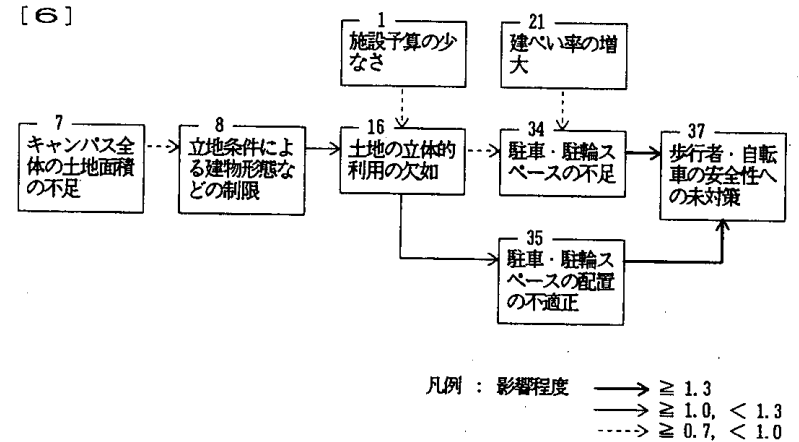

図一5 主要な影響ルート
への影響も大きく効果的であると思われる。

(4) 相互影響関係にある [20，将来計画用地の配置の不 適正］亡 [17. 建物密度のかたより 計画の不適正] の解決によってある程度解決できるが， その妨げとして [11．組織の独立性への指向となわばり 意識], [4. 計画内容の不備・有効な計画手法の欠如], [9.敷地条件による制限] があげられる。現在の国立大 学では, 学部の独立性が強く一度設定したゾーンを変更 することが困難なため, 施設増加量の多い学部と少ない 学部で建築密度や将来計画用地面積に差が生じている。 組織間の利害を調整し，全学的な立場で計画を策定する ことが重要であると思われる。

（5）［1・施設予算の少なさ]， [13，建物面積基準による 面積拡大要求への制限］による [24. 施設面積の不足], [27. 共同利用施設面積の不足] は， [30. 交流の場・休 息の場の不足]，[29. 施設・環境デザインの欠如］をも たらしている。つまり各学部・学科などでは施設面積が 不足しているため大部分が研究室, 実験室などに取られ ていることにより，ロビー・ラウンジなどの確保が困難 であることがうかがわれる。

(6) [35. 駐車・駐輪スペースの配置の不適正], [34. 駐車・駐輪スペースの不足 ]， [37．歩行者・自転車の安 全性への未対策］などの交通問題は, 現在の大学に共通 した重大な問題である。その解決法として [21．建ぺい 率の増大］以外では [16. 土地の立体的利用] が有効で あるが，[1．施設予算の少なさ]，８．立地条件による 建物形態などの制限］がそれを困難にしている。土地の 有効利用の具体的方策となる地下駐車場，立体駐車場の 建設なよ゙に，予算的対応が求められていると思われる。

\section{5. まとめ}

国立大学におけるキャンパス計画と施設・環境に関す る問題の全体構造を明らかにするために，構造モデル法 の一種であるDEMATEL 法を適用した。その結果, 以下に示すことが明らかになった。

（1）DEMATEL 法を用いることによって，複雑な問 題複合体を形成している国立大学のキャンパス計画と施 設・環境に関する問題全体の構造を, 各大学の施設担当 者の認識を通して明確化することができた。

（2）関連度一影響度の分析および構造モデルの多階層 有向グラフ表示により, 個々の問題を他の問題との関係 により位置づけた。他の問題に大きな影響を与える先行 問題としては, 将来予測の問題, 組織間の協力の問題, 施設予算, 面積基準なよ゙の施設行政の問題など計画に関 する問題があげられ，これらが有効な施設計画が策定で きない原因であることが明らかとなった。また，他の問 題から影響を受ける目標問題としては, 駐車場などの交 通問題, 緑地・広場, 施設デザインなどの快適環境の問 
題, 学部・学科のまとまり, 関連学部・学科のつながり など施設配置の問題があげられた。

（3）問題間の影響関係より主要なルートを抽出するこ とができ, 次のような問題解決のために有効な知見を得 た。

(1) 建設プロセスの決定の難しさを解決するために, 施 設面積基準の制限や建物取り壊しの制限の緩和, 有効な 計面手法の開発, 組織間の協力が必要である。

(2) 施設予算の増大と組織同士の協力により，できるだ け建物を高層化・大規模集約化し，その結果として将来 計画用地を適切な位置に確保することが重要である。

(3) 建設プロセスの決定の難しさ, 増築などに対応しに くい建築群の形態, 関連学部・学科のつながりの欠如, 建物の小規模化・細分化, 建物の高層化の難しさ, 建ぺ い率の増大, 将来計画用地面積の不足, の問題はサイク ルを形成しており，このサイクルを断つことが重要な課 題である。

(4) 施設や将来計画用地を適切に配置するためには，組 織間の協力や有効な計画手法の開発により適切なゾーン 計画を行う必要がある。

(5)良好な施設・環境デザインの形成や生活スペースの 充実のために面積基準の拡大, 施設予算の増大が必要と されている。

(6) 駐車スペースの不足の対策として立体駐車場や地下 の利用をはかるための予算的措置が必要とされている。

(4) 得られた構造モデルは施設担当者の認識に基づい ており, 利用者側ではなく, 整備を進めるという立場か らの見解が現れている。特に, 問題項目の重要性に対す る評価において, 生活スペースの充実や施設の配置に関 する問題に比較して, 駐車場, 設備, 施設面積など現実 に直面している問題を重視する傾向がみられる。実際の 計画策定の際には, 教職員・学生からの意見も十分に聴 取する必要があると思われる。

（5）以上より考察すると, キャンパス計画と施設・環 境に関する問題の解決のためには, 施設行政おいては施 設予算および基準面積などの問題に対策を講ずること, また個々の大学では教職員・学生を含めた大学全体の意 見をまとめることのできる計画プロセスと計画組織を確 立することが必要であり, 施設行政側と各大学の計画組 織との間にキャンパス計画に関する有効な情報交換のシ ステム構築が重要な課題と考えられる。

\section{謝 辞}

本研究に当たって調査にご協力いただきました国立大 学施設部課の関係各位に心から謝意を表します。また, 調查・分析には, 横山護氏 (当時東京工業大学) の協 力を得た。ここにお礼を申し上げます。
注

1）文部省では，大学キャンパスのことを団地と称し，「国立 大学の施設が存在するか, また施設を整備しようとして いる一団地の土地をいう。また，一団地とは，用途上不 可分の関係にあり，まとまった一区画の土地と社会通念 上喼められている土地をいう。」と定義している。本研究 でも, 回答者が施設部課のため調查票の中では「団地」 を使用しているが，本稿では「キャンパス」を用いた。

2）文献 10), 12), 16), 17)，20）など。

3) 文献 7), 14) など。

4）文献 5), 8), 13)，18）など。

5）文献 4), 15), 21) など。

6）文献 6), 11), 14) など。

7）文献 9), 14), 19) など。

8）ISM (Interpretive Structural Modeling) 法は, 複雑な 社会システム問題の全体像を, 構成要素の相互関係をも とにした多階層有向グラフとして図示し, 問題の構造を 解明しようとする方法である。文献 22)，23），27)２9）, 31) 34) 参照。

9) DEMATEL (Decision Making Trial and Evaluation Laboratory）は，世界が直面している複雑・困難な問題 を解決しようというバテル研究所の大規模な研究プロ ジェクトの名称である。DEMATEL 法は，その中で世 界問題の構造把握を目的として提案された方法論の一つ である。文献 22) -26)，30）参照。

10）非常に問題となっている, 問題となっている, やや問題 となっている, あまり問題となっていない, 問題となっ ていない,の 5 段階で回答を求めた。

11) 非常に重要, 重要, やや重要, あまり重要でない, 重要 でるい,の5段階で回答を求めた。

12）強，中，弱の 3 段階で回答を求めた。

13）既往研究や筆者らが今までの大学施設研究を通して得た 知識をもとに，20 の評価項目を作成し，国立大学施設部 課に対する郵送によるアンケート各項目に対する 5 段階 評価を得た。また，施設整備を行ううえで 20 項目以外に 問題になっていることについても自由形式での回答を求 めた。

14）まず工科系学部施設の分析と大学施設関連の既往研究 · 文献の調查から得られた問題項目のリストを作成した。 このリストを 3 名の国立大学施設部長に送付し, 電話に よるヒヤリングにより問題項目の変更・追加・削除など の意見を得た。

15） システムの構成要素 $s_{i}$ の影響関係が $s_{1} \rightarrow s_{2} \rightarrow s_{3} \rightarrow s_{4} \rightarrow s_{5}$ $\rightarrow s_{1}$ のように循環しているとき,これらの要素をサイク ルという。

\section{参考文献}

1）山口勝巳, 谷口汎邦, 高野文雄: 施設管理者からみた工 科系学部施設の物的環境評価一大学キャンパスの計画に 関する研究 その 9 一, 日本建築学会大会学術講演梗概 集E, pp. 561 562, 1989 年

2）山口勝巳, 谷口汎邦, 高野文雄, 横山 護: 国立大学団 地における施設・環境問題の構造化一大学キャンパスの 計画に関する研究 その11一, 日本建築学会大会学術講 演梗概集 E, pp. $365 \sim 366,1990$ 年

3）丸茂弘幸: 国立大学キャンパスにおける土地利用の低効 率化要因に関する研究, 日本都市計画学術研究論文集, 
24 号, pp. 181 186, 1989 年

4) 足立 孝, 岡田光正ほか：大学構内の駐車台数について, 日本建築学会論文報告集号外，p. 482，1965 年

5）足立 孝, 岡田光正ほか：大学食堂の規模算定について, 日本建築学会近畿支部研究報告集, pp. 33 36, 1966 年

6) 足立 孝, 岡田光正ほか:キャンパスの内に於ける学生 の分布, 日本建築学会近畿支部研究報告集, pp. $41 \sim 44$, 1967 年

7）足立 孝, 紙野佳人：大学施設配置の計画に関する考察, 日本建築学会論文報告集号外, p. 477, 1965 年

8）川崎 清, 笹田剛史: 大学の施設計画について一施設構 成と規模因子について一, 日本建築学会論文報告集, 133 号, pp. 38 43, 1967 年

9）小林秀弥：大学のキャンパス計画, 彰国社, 1978 年

10）小林正美, 東山純一, 川崎 清: 京都大学吉田キャンパ スの外部空間に対する意識分析, 日本建築学会計画系論 文報告集, 378 号, pp. 58 65，1987 年

11）瀬口哲夫, 湯谷 操: 大学キャンパスにおける人間行動 の研究一その 1 その 5 , 日本建築学会大会学術講演梗概 集, 1982 1984 年

12）瀬口哲夫, 梅崎直人ほか：キャンパスモールの評価に関 する研究 (1) （4)，日本建築学会大会学術講演梗概集， 1985 1987 年

13）高野文雄, 谷口汎邦ほか：国立大学学部校舎の建築計画 に関する基礎的研究 その $1 \sim$ その 10 , 日本建築学会大 会学術講演梗概集, 1985 1991 年

14）谷口汹邦, 山口勝巳ほか：大学キャンパス計画に関する 研究 その1 その 13 , 日本建築学会大会学術講演梗概 集, 1984 1991 年

15）土肥博至ほか：大学キャンパスにおける交通流動の研究 (1) ～( 8 ), 日本建築学会関東支部学術研究発表会, 1978 1979 年

16）土肥博至, 志田隆秀ほか：外部空間の構成に関する研究 (1) ～( 6 ), 日本建築学会大会学術講演梗概集，1978 1980 年

17）中田裕久, 土肥博至, 志田隆秀 : 都市空間の認知・評価 に関する研究一その 1 初期の環境の認知-評価-行動の 構造一, 日本建築学会計画系論文報告集, 306 号, pp. 115 125，1981 年

18）長倉康彦，上野 淳，中橋 徹：大学における校舎の面 積構成に関する実態分析, 日本建築学会大会学術講演梗 概集，pp. 1277 1278，1978 年

19）長倉康彦, 原坦, 関 日出夫, 中橋 徹 : 大学キャ ンパスの土地利用について, 日本建築学会大会学術講演 梗概集，pp. 923〜924，1977 年
20）宮本文人，谷口汎邦ほか：大学キャンパスにおける建築 外部空間の構成計画に関する研究 その 1 その 4 , 日本 建築学会計画系論文報告集, 348 号, 358 号, 364 号, 381 号, $1985 \sim 1987$ 年

21）吉武泰水，船越 徹ほか：キャンパス設計計画に関する 研究 1 4, 日本建築学会論文報告集号外, 1967 1968 年

22）椹木義一，河村和彦 (編)：参加型システムズ・アプロー チ一手法と応用一, 日刊工業新聞社, 1981 年

23）寺野寿郎：システム工学入門一あいまい問題への挑戦一, 共立出版, 1985 年

24）折田仁典，清水浩志郎：DEMATEL 法による過疎問題 の構造化に関する基礎的研究，日本都市計画学会学術研 究論文集, 23 号, pp. $289 \sim 294,1988$ 年

25）宮崎洋二，熊田禎宣：住宅関連専門家からみた首都圈自 治体の建て替え問題と政策の整合性に関する考察，日本 都市計画学会学術研究論文集, 24 号, pp. 157 162, 1989 年

26）北垣郁夫，多賀谷敏夫：作業的な訓練にかかわる意識構 造の抽出一DEMATEL 法による, 日本教育工学雑誌, 13 巻, 1 号, pp. $29 \sim 37,1989$ 年

27）田村坦之：構造モデリング一理論とアルゴリズムを中心 にして一, 計測と制御, 18 巻, 2 号, pp. 170 179, 1979 年

28）田村坦之：ISM 構造モデル一制御理論と実際一, 計測と 制御, 18 巻, 10 号, pp. 869 872, 1979 年

29）星谷 勝, 大野春雄, 山本欣弥：あいまい理論によるラ イフライン機能の震災影響波及の構造化, 土木学会論文 集, 344 号, pp. 323 331，1984 年

30) Fontela, E. and Gabus, A. : DEMATEL Reports, Battelle Geneva Research Centre, 1973 1976

31) Warfield, J. N. : On Arranging Elements of a Hierarchy in Graphic Form, IEEE Trans. Syst., Man, Cybern., Vol. SMC-3, No. 5, pp. 121 132, 1973

32) Warfield, J. N. : Binary Matrices in System Modeling, IEEE Trans. Syst., Man, Cybern., Vol. SMC-3, No. 5 , pp. $441 \sim 449,1973$

33) Warfield, J.N. : Toward Interpretation of Complex Structural Models, IEEE Trans. Syst., Man, Cybern., Vol. SMC-4, No. 5, pp. 441 449, 1974

34) Warfield, J. N. : Societal Systems......Planning, Policy and Complexity, J. Wiley \& Sons, 1976

(1991 年 10 月 9 日原稿受理, 1992 年 6 月 16 日採用決定) 